\title{
IbM DASA WISMA BUDIDAYA STROBERI LOKAL DI KAMPUNG TENGAH
}

\author{
Miranti Sari Fitriani, Jasminarni, Evita dan Trias Novita \\ Dosen Fakultas Pertanian Universitas Jambi \\ Kampus Pinang-Masak, Mendalo Indah Jambi 36361 \\ email : miranti_sari@yahoo.com; jasminarnidjanan@ymail.com; evitae@ymail.com; \\ vita_dinni@yahoo.com
}

\begin{abstract}
ABSTRAK
Kegiatan ini bertujuan meningkatkan pengetahuan dan ketrampilan kelompok dasa wisma lembayung dan kelompok dasa wisma sedap malam di Desa Kampung Tengah melalui pendampingan, penyuluhan dan demontrasi tentang tehnik pembuatan kompos limbah pabrik teh dan perbanyakan stroberi. Tanaman stroberi didaerah ini merupakan tanaman yang tumbuh liar tanpa memperhatikan aspek budidaya yang baik terutama dalam pemeliharaan dan pengendalian hama dan penyakit. Tanaman Stoberi mempunyai potensi ekonomi yang tinggi karena harga jual buah yang dihasilkan cukup mahal, bentuk dan rasa buahnya sangat disukai dan tergolong buah-buahan langka untuk daerah-daerah di sumatera. Buah stroberi ini dapat dikosumsi segar ataupun diolah untuk berbagai industri seperti pembuatan jelly, sirup atau juice dan penambah aroma bahan makanan lainnya. Bahan organik yang dapat dimanfaatkan, salah satunya adalah limbah pabrik teh, yang saat ini kurang dimanfaatkan. Limbah padat industri teh ternyata dapat dimanfaatkan untuk berbagai keperluan antara lain menjadi bahan baku pembuatan pupuk organik. Ampas teh yang akan dijadikan pupuk tanaman, diproses melalui pengolahan secara termofil. Caranya, ampas teh dari sisa penyeduhan di letakkan pada bak atau tempat khusus yang telah disediakan, kemudian dan didinginkan selama satu hari. Mikroorganisme ditambahkan untuk mempercepat proses penguraian dan dilanjutkan dengan proses pembalikan dalam seminggu sekali. Kompos siap digunakan setelah proses fermentasi berlangsung selama kurang lebih satu bulan. Secara umum target luaran yang akan dicapai akan memberi dampak terhadap Masyarakat umumnya dan kelompok dasa wisma lembayung serta dasa wisma sedap malam khususnya serta masyarakat disekitarnya. Dampak positif yang diharapkan tercapai melalui kegiatan ini dimana tim pengabdiaan akan melakukan pelatihan, demontrasi dan demplot untuk dasa wisma lembayung dan dasa wisma sedap malam dalam hal mengolahan limbah pabrik teh menjadi kompos yang akan dimanfaatkan sebagai media pada perbanyakan stroberi lokal. Dengan cara ini dapat menekan biaya produksi yang harus dikeluarkan, karena untuk pembelian pupuk sudah dapat ditekan dengan pemakaian kompos yang di hasilkan sendiri serta dapat menghindari pencemaran lingkungan dari pemakaian pupuk kimia. Target luaran yang dapat diharapkan dari kegiatan ini adalah meningkatnya pengetahuan kelompok dasa wisma akan pemanfaatan limbah pabrik teh dan pembudidayaan tanaman stroberi lokal sehingga akan di hasilkan kompos limbah teh dan stroberi lokal organik.
\end{abstract}

\section{Kata Kunci : Kompos Limbah Teh, Stroberi Lokal Organik.}

\section{PENDAHULUAN}

Kota Sungai Penuh merupakan daerah pegunungan yang ada di Propinsi Jambi, dengan ketinggian tempatnya kira-kira 1000-1600 diatas permukaan laut, berhawa sejuk dengan curah hujan cukup tinggi. Dilihat dari keadaan iklimnya maka sangat mendukung sekali dalam 
membudidayakan Stroberi yang butuh suhu rendah dan kelembaban yang tinggi. Dinas Pertanian, Perkebunan dan Kehutanan kota Sungai Penuh juga sudah mulai melirik adanya kemungkinan pengembangan budidaya tanaman ini terutama untuk jenis strowberi lokal yang saat ini hampir punah.

Tanaman strowberi didaerah ini merupakan tanaman yang tumbuh liar tanpa memperhatikan aspek budidaya yang baik terutama dalam pemeliharaan dan pengendalian hama dan penyakit. Tanaman Stroberi mempunyai potensi ekonomi yang tinggi karena harga jual buah yang dihasilkan cukup mahal, bentuk dan rasa buahnya sangat disukai dan tergolong buah-buahan langka untuk daerah-daerah di sumatera. Buah stroberi ini dapat dikosumsi segar ataupun diolah untuk berbagai industri seperti pembuatan jelly, sirup atau juice dan penambah aroma bahan makanan lainnya.

Saat ini media tumbuh yang digunakan adalah tanah, sebagai pupuk digunakan pupuk mutiara (pupuk kimia) sedangkan untuk memberantas hama dan penyakit digunakan pestisida kimia yang tersedia dipasaran. Untuk menhasilkan strowberi organik yang bebas pestisida dapat dilakukan dengan menerapkan pertanian organik.

Pertanian organik adalah cara menanam tanaman secara alami dengan penekanan terhadap perlindungan lingkungan dan pelestarian tanah serta sumber air kita yang berkelanjutan. Pertanian organik tidak menggunakan pupuk buatan yang berasal dari bahan bakar minyak, pestisida, atau makanan dari hasil modifikasi genetika. Pertanian organik sebaliknya menggunakan pestisida biologi tanpa kimia yang diatur secara ketat sehingga melindungi tanah, udara, makanan, dan hewan liar dari bahaya kimia yang biasa digunakan dalam pertanian konvensional. Salah satu pupuk organik yang biasa digunakan adalah kompos yang berasal dari limbah organik yang ada disekitarnya.

Bahan organik yang dapat dimanfaatkan, salah satunya adalah limbah pabrik teh, yang saat ini kurang dimanfaatkan. Limbah padat industri teh ternyata dapat dimanfaatkan untuk berbagai keperluan antara lain menjadi bahan baku pembuatan pupuk organik. Ampas teh yang akan dijadikan pupuk tanaman, diproses melalui pengolahan secara termofil. Caranya, ampas teh dari sisa penyeduhan di letakkan pada bak atau tempat khusus yang telah disediakan, kemudian dan didinginkan selama satu hari. Mikroorganisme ditambahkan untuk mempercepat proses penguraian dan dilanjutkan dengan proses pembalikan dalam seminggu sekali. Kompos siap digunakan setelah proses fermentasi berlangsung selama kurang lebih satu bulan.

Limbah padat industri teh ternyata dapat dimanfaatkan untuk berbagai keperluan antara lain menjadi bahan baku pembuatan pupuk organik. Ampas teh yang akan dijadikan pupuk tanaman, diproses melalui pengolahan secara termofil. Caranya, ampas teh dari sisa penyeduhan di letakkan pada bak atau tempat khusus yang telah disediakan, kemudian dan didinginkan selama satu hari. Mikroorganisme ditambahkan untuk mempercepat proses penguraian dan dilanjutkan dengan proses pembalikan dalam seminggu sekali. Kompos siap digunakan setelah proses fermentasi berlangsung selama kurang lebih satu bulan.

Kelompok dasa wisma lembayung dan dasa wisma sedap malam di desa Kampung Tengah yang masing-masingnya terdiri dari 10 kepala keluarga, akan menjadikan strowbery ini sebagai salah satu tanaman yang dapat membantu kebutuhan keluarga sebagai salah satu 
sumber buah, disamping mereka dapat melestarikan tanaman stroberi lokal yang hampir musnah. Tanaman stroberi ini diusahakan menjadi tanaman pekarangan pada lahan-lahan sempit di daerah perkotaan. Stroberi bisa dibudidayakan didalam wadah berbentuk polibag, pot atau bahan-bahan lainnya. Seperti pada kedua dasa wisma ini kerena rata-rata mereka memiliki lahan sempit maka penanaman dilakukan dengan menggunakan wadah polibag.

Oleh karena itu dirasa perlu untuk menerapkan tekhnik budidaya tanaman strowberi secara organik pada masyarakat setempat, dengan memanfaatkan kompos limbah pabrik teh sebagai pupuk sebagai pengganti pupuk kimia yang akhirnya dapat mengurangi biaya produksi dan menghasilkan buah stroberi yang bebas pestisida.

\section{METODE PELAKSANAAN}

Target luaran yang diharapkan dalam pengabdian ini berdasarkan tahapan pelaksanaan kegiatannya dapat bersifat langsung (direct effects) maupun tidak langsung (indirect effects). Target luaran yang bersifat langsung adalah hasilnya dapat langsung dirasakan masyarakat khususnya kelompok dasa wisma lembayung dan dasa wisma sedap malam di desa Kampung Tengah dengan cara mengelola pekarangan mereka untuk perbanyakan tanaman stroberi lokal menggunakan kompos limbah pabrik teh untuk menghasilkan stroberi lokal organik. Budidaya stroberi organik ini dapat membantu mereka dalam meningkatkan perekonomian keluarga dan pemenuhan buah-buahan bagi keluarga. Secara umum target luaran yang akan dicapai akan memberi dampak terhadap lingkungan dasa wisma lembayung dan dasa wisma sedap malam desa Kampung Tengah maupun wilayah sekitarnya.

Dampak positif yang diharapkan tercapai melalui kegiatan ini dapat dinilai dengan pemanfaatan limbah pabrik teh sebagai kompos yang akan digunakan pada budidaya stroberi organik. Sedangkan manfaat yang tidak dapat dinilai dengan harga pasar adalah lingkungan yang sehat dan bersih serta stroberi yang bebas dari pestisida. Disamping itu target lain adalah mengupayakan kesadaran masyarakat umumnya untuk dapat memanfaatkan limbah pabrik teh sebagai bahan baku kompos sebagai pengganti pupuk kimia Jadi disini luaran yang diharapkan adalah berupa produk yaitu: Kompos dan stroberi lokal organik.

\section{HASIL DAN PEMBAHASAN}

Program pengabdian ini berupaya memberi solusi untuk memanfaatkan limbah pabrik teh dan pupuk kandang menjadi kompos organik dengan biostarter trichoderma. Limbah pabrik teh yang menumpuk dipabrik dapat digunakan untuk media budidaya stroberi lokal, selama ini limbah pabrik teh dibiarkan menumpuk ditempat pembuangannya di pabrik teh Kayu Aro dan tidak dimanfaatkan. Pemanfaatan limbah pabrik ini juga dapat membantu menghindari polusi lingkungan.

Kompos organik berbahan baku limbah teh ini dapat dipakai pula oleh kelompok dasa wisma sebagai pengganti pupuk kimia yang biasa mereka gunakan untuk tanaman lainnya yang mereka tanam disekitar pekarangannya.

Pada pengabdian Ibteks bagi Masyarakat ini dilakukan penyuluhan, pelatihan dan demontrasi bagaimana cara memperbanyak sroberi lokal dan membuat kompos dari limbah 
pabrik teh dengan memakai trichoderma biostarter, dan kompos ini dipakai sebagai pengganti pupuk kimia pada budidaya stroberi .

Penyuluhan yang diberikan dapat menambah pengetahuan kelompok dasa wisma tentang manfaat pupuk organic secara umum dan kompos limbah pabrik teh khususnya. Disamping itu juga menambah pengetahuan masyarakat tentang tanamn organic umumnya. Penyuluhan diberikan pada dua kelompok dasa wisma dengan harapan agar dapat ditularkan pada kelompok dasa wisma atau masyarakat lainnya.

Demontrasi pembuatan kompos berbahan baku limbah pabrik teh ini langsung dipraktekan bersama sama kelompok dasa wisma, sehingga mereka dapat mencoba langsung di lapangan. Perbanyakan bibit stroberi juga dilakukan dengan cara demontrasi. Cara ini dapat membantu kelompok dasa wisma dalam meningkatkan pengetahuan mereka tentang tekhnik perbanyakan bibit stroberi lokal yang sebenarnya sudah sukar didapat.

Pelatihan dilakukan kelompok dasa wisma dengan cara melatih diri dengan membudidayakan tanaman stroberi local di lahan pekarangan mereka. Dari hasil budidaya stroberi lokal di pekarangan ini dapat dimanfaatkan masyarakat sebagai sumber buah-buahan keluarga dan penambah penghasilan ekonomi keluarga karena stroberi dapat mereka jual di pasar tradisional dengan harga yang cukup tinggi (1 pak isi 150 gram ) yakni Rp 10.000 / pak.

Kompos yang dihasilkan juga di jual pada warga sekitar yang memerlukannya. Disamping digunakan mereka sendiri untuk menggantikan pupuk kimia yang biasa mereka pakai pada budidaya sayuran. Dengan demikian mereka dapat menghasilkan sayuran organic yang sehat diamping dapat menekan biaya produksi pertanian mereka.

Kegiatan yang sudah dilaksanakan selama pengabdian ini dapat dilihat pada foto-foto di bawah ini.

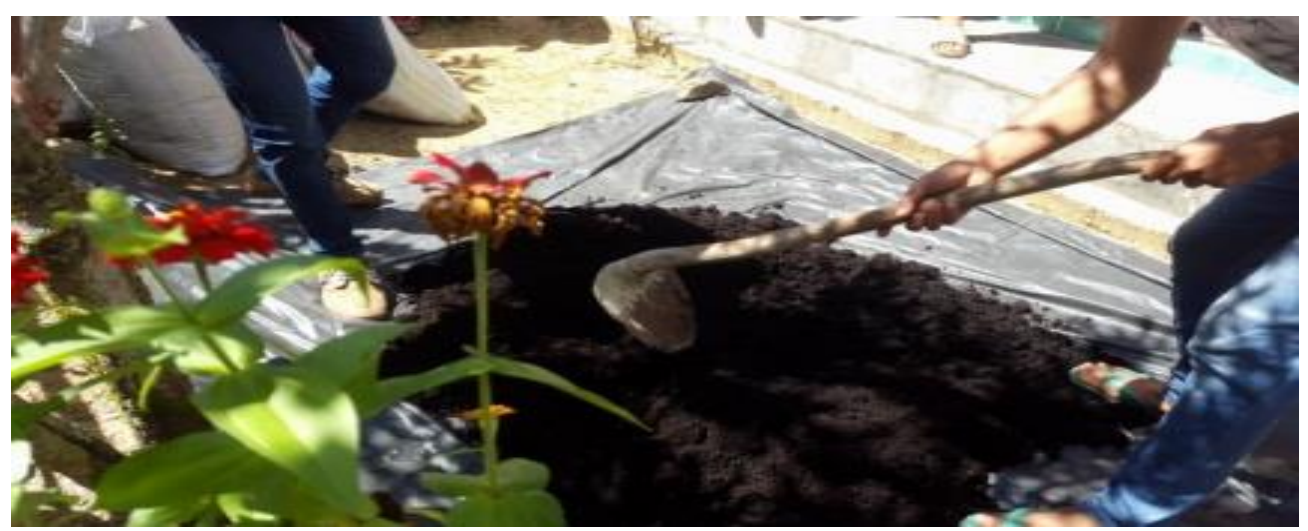

Gambar 1. Demontrasi Pembuatan Pupuk Limbah Teh

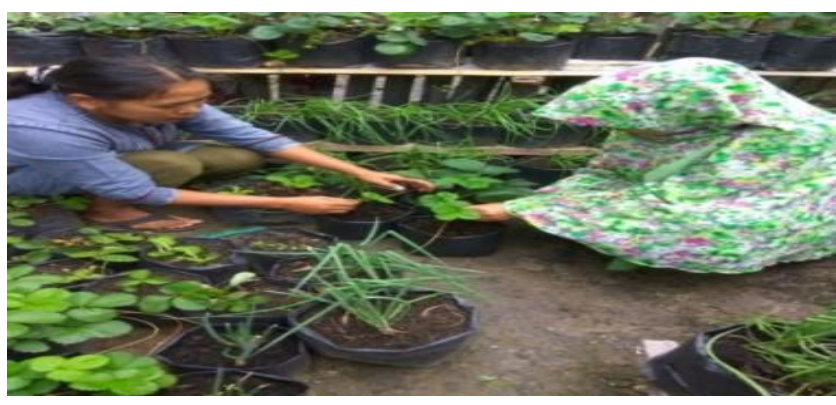


Gambar 2. Demontrasi Perbanyakan Tanaman Stroberi

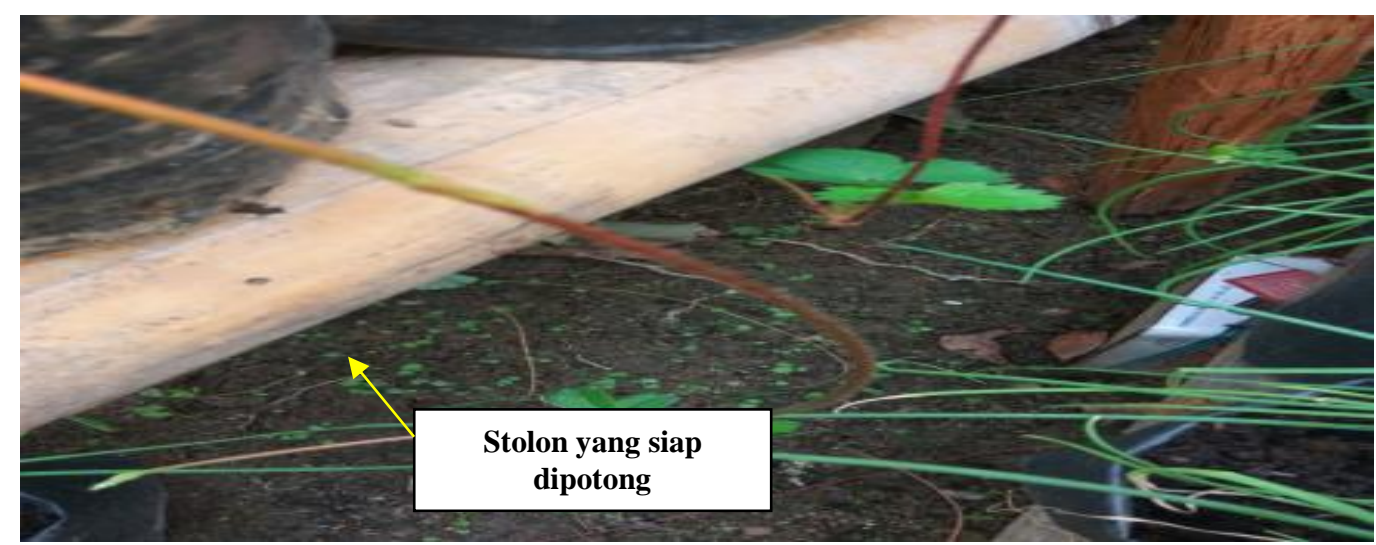

Gambar 3. Stolon Stoberi yang Siap di Bibitkan
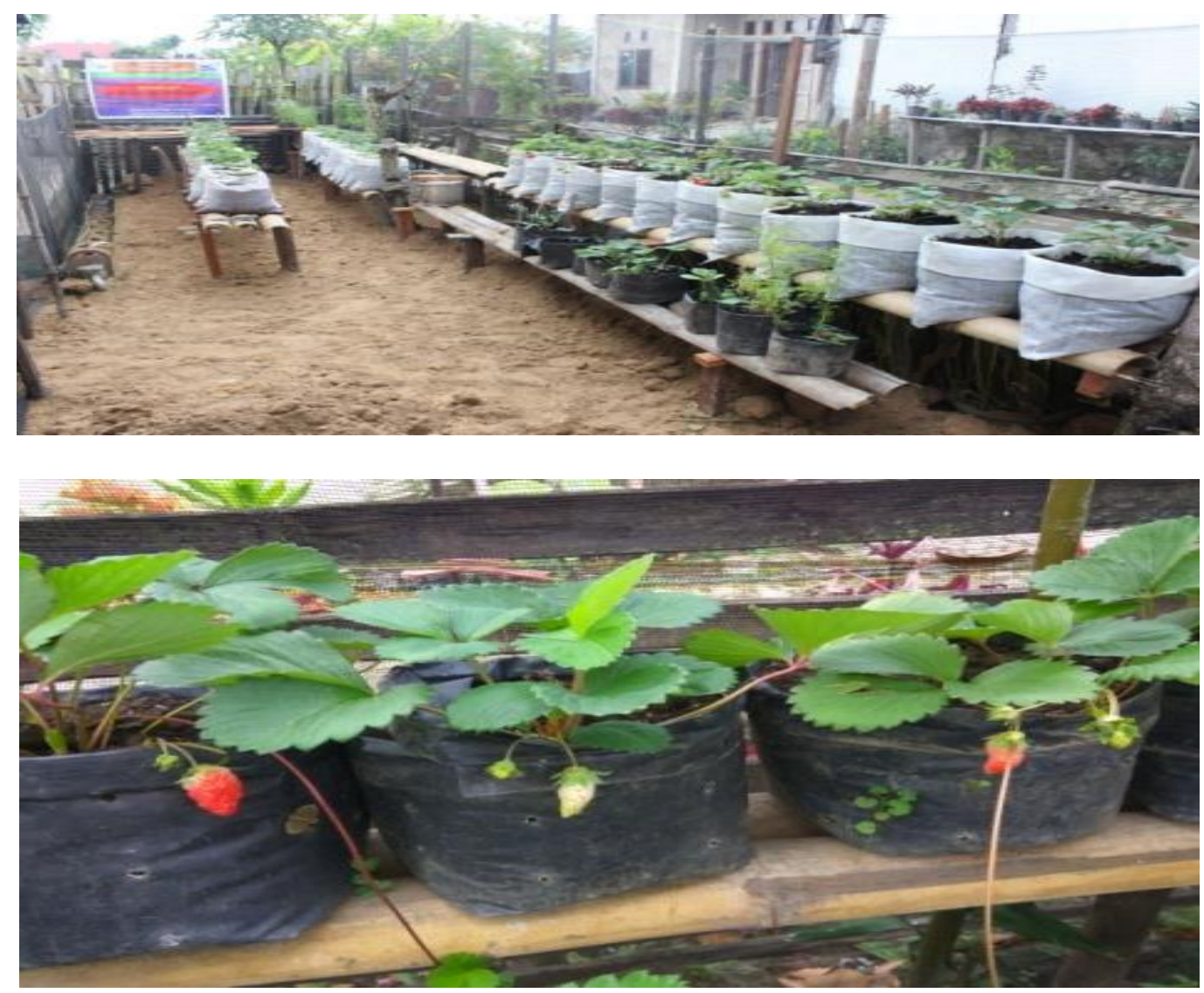

Gambar 4. Tanaman Stroberi di Pekarangan

\section{KESIMPULAN}

1. Masyarakat mulai mengenal limbah pabrik teh yang dapat digunakan sebagai bahan baku kompos. 
2. Masyarakat dapat menjadikan stroberi lokal ini sebagai variasi buah yang dikosumsi dan dapat dipelihara disekitar pekarangan baik menggunakan polibag ataupun langsung ditanam di tanah.

3. Stroberi yang dihasilkan juga dapat meningkatkan perekonomian keluarga karena hasilnya juga dapat diasarkan di pasar-pasar tradisional.

\section{UCAPAN TERIMA KASIH}

Terima kasih penulis ucapkan kepada Direktorat Riset dan Pengabdian Kepada Masyarakat Direktorat Jendral Penguatan Riset dan Pengembangan Kementrian Riset, Teknologi dan Pendidikan Tinggi, yang telah mendanai pengabdian ini sesuai dengan Surat Perjanjian Penugasan Pelaksanaan Program Pengabdian Kepada Masyarakat Nomor SPPDIKTI : 022/SP2H/PPM/DRPM/IV/2017 tanggal 3 April 2017.

\section{DAFTAR PUSTAKA}

Ariani dan Sri Retno Dewi, 2007.Peningkatan Kualitas dan Kuantitas Produksi buahStrawberry di daerah Tawangmangu melalui penerapan pola tanam secara organik. http : / www. Lppm.uns.ac.id/. Diakses 14 November 2015

Gunawan, Livy Winata 1996. Stroberi. Jakarta : Penebar Suadaya

Rukmana, R 1998. Stroberi Budidaya danPascapanen. Penerbit Kanisius

Sutanto, R. 2002. Penerapan Pertanian Organik. Yogyakarta: Kanisius

Sarwono, B. 2005. Cara budidaya yang tepat, efisien dan ekonomis - Jakarta : Penebar Swadaya 